\title{
Resource-saving technologies for preparing fodder crops
}

\author{
Tatiana Marinchenko* \\ Rosinformagrotekh, Pravdinsky Township, Moscow Region 141261, Russia
}

\begin{abstract}
A modern animal husbandry needs balanced feeding with rational use of feed and the maximum involvement of unconventional feed. At the same time, issues of increasing the nutritional value of feeds, improving quality, reducing the share of cereals remain urgent, since they occupy a significant part in the composition of the diet and cost structure. The application of modern feed processing technologies increases the efficiency of their use, increases the performance of animal husbandry, as evidenced by numerous experiments. The organization of feed production based on own feed resources significantly reduces the cost of production. The application of a number of technologies has been discussed and justified, which allows obtaining feed with high zootechnical and consumer characteristics, as well as with high rates of nutrition, digestibility and biological value with a significant reduction in the cost of feeding.
\end{abstract}

\section{Introduction}

To achieve the strategic goal of the country's innovative development, it is fundamentally important to further develop scientific and technological innovations in agriculture and develop modern agriculture in the direction of increasing production efficiency, product safety, resource saving and environmental friendliness of production [1].

The issue of feed supply is fundamental for livestock farms, poultry farms, and also fisheries, and is crucial in the production economy and its competitiveness.

High productivity of farm animals and poultry, as well as rational consumption of feed, are achieved by balanced rationed feeding, which ensures not only full-fledged growth and productivity, but also a minimum feed consumption per unit of output.

The efficiency of livestock production is directly dependent on the level of organization of feeding; therefore, processes are underway to improve the technical means and technologies for the preparation and processing of feed. Particular attention is paid to improving the nutritional value of feeds, improving the quality, efficient use of raw materials, including the rational use of cereals, since they occupy a significant part of the diet and cost structure.

Therefore, many manufacturers are faced with the problem of both increasing the feed value and quality of existing feed products while reducing their cost, and the involvement of production waste, the search for new sources of feed or alternative ways to obtain them.

About half of the gross crop production is straw and tops of agricultural plants, only half of the straw and not more than $30 \%$ of tops are used for livestock feed. The remaining straw and tops are practically not used; they are burned or decayed in the fields or in places of temporary storage. In many regions, there are large amounts of underutilized or generally unused wastes of crop production that are being constantly accumulated.

The amounts of produced raw materials, which are hardly used, but potentially suitable for feed purposes, are many times greater than the amounts of specially produced feed components [2].

The problem of finding new and alternative ways to obtain feed, improve their quality while reducing production costs, as well as the development of related energy sources is especially urgent today and is one of the main tasks of the agricultural sector.

It remains relevant to improve the digestibility of feed grain, which is the main component of animal feed for farm animals. One of the methods for increasing the digestibility of grain is its extrusion [3].

Numerous domestic and foreign studies have found that the productivity of farm animals and poultry depends on the quality of feed to be consumed by 50-60\%, therefore, ensuring the sanitary and hygienic parameters of finished feeds and their components remains the focus of research interest and is a factor in allowing them to be fed [4].

The use of modern feed processing technologies (pelletizing, extrusion, expansion, micronization, etc.) increase the efficiency of their use and the weight gain of animals [5].

At the same time, a number of factors have a significant impact on fodder production: a shortage of feed grain and competition with food production regarding low-grade food grain; loss and spoilage of grain during harvesting and storage; a shortage of equipment during the harvesting period due to the need to harvest a large number of different crops in relatively short deadlines; traditionally high grain content in domestic feed formulations leading to an annual high demand for feed grain.

*Corresponding author: 9419428@mail.ru 
For many manufacturers, the cost of feed can be significantly reduced by organizing feed production based on their own feed resources, involving waste from agriculture, livestock and crop production, secondary raw materials from the processing and food industries, and using modern feed preparation technologies that increase the feed quality of feeds.

\section{Results and discussion}

Sustainable increase in grain production is the most important problem of the country's agricultural sector. Food security is a part of Russia's national security, one of the critical indicators of which is gross grain harvest, including seed stock, commodity and feed grain, according to the needs of the population and livestock, as well as the objectives for export development.

In Russia, in recent years, the gross grain harvest is at a fairly high level being about 120 million metric tons. According to the State Program for the Development of Agriculture, the volume of production of grain and leguminous crops must be increased to 141.9 million metric tons by 2025 .

In general, the growing volumes of gross harvests of grain crops are of heterogeneous quality, which is influenced by weather conditions, natural soil fertility and specific agricultural technologies of producers. According to the Russian Agricultural Center, the share of food wheat exceeded $80 \%$ in the 2019 crop [6].

According to the Long-term Strategy for the Development of the Grain Complex of the Russian Federation until 2035 (hereinafter referred to as the Strategy), the grain consumption in Russia will amount to 86.6 million metric tons, including 52.3 million metric tons to be used for the production of animal feed and compound feed, by 2035 [7].

Against the background of growing production, experts note a constant shortage of feed grain, which is covered with food grain, mainly wheat, creating competition for food production, which increasingly involve low-grade grain in processing.

A factor that has a significant impact on the efficiency of grain production is the organization of harvesting campaign. The grown crop must be harvested in a short time to avoid spoilage and losses, including direct (loss of grain shedding and sprouting, breaking off spikes and losses from pests and birds) and indirect (loss of grain quality associated with violation of harvesting terms) biological or natural losses. The observance of harvesting terms remains a critical factor: already in the first days after full ripeness, the yield is noticeably reduced. So, in 4 to 5 days after full ripeness, grain losses of spring wheat are up to 2 hundredweight per ha; in the case of a delay of harvesting up to 20 days, they can reach 7.5 hundredweight per ha for spring wheat, 8.8 hundredweight per ha for spring barley, and 8.4 to 8.8 hundredweight per ha for oats.

A more than 15-day delay in harvesting leads to a loss of up to a third of the crop when its quality deteriorates. The greatest grain crop loss is observed from the $8^{\text {th }}$ to the $15^{\text {th }}$ day of harvesting after the full ripeness of the grain.
Loss of grain for each day of dead-ripe stage ranges from 21.6 to $35.9 \mathrm{~kg}$ / ha or from 0.9 to $1.5 \mathrm{~kg}$ / ha depending on the crop (Table 1) [2].

Table 1. Grain losses during harvesting after full ripeness for each subsequent day or hours of dead-ripe stage.

\begin{tabular}{|l|c|c|c|c|}
\hline \multirow{2}{*}{ Crop } & \multicolumn{4}{|c|}{ Average grain loss } \\
\cline { 2 - 5 } & \multicolumn{2}{|c|}{$[\mathrm{kg} / \mathrm{ha}]$} & \multicolumn{2}{c|}{$[\%$ of crop] } \\
\cline { 2 - 5 } & $\begin{array}{c}\text { Per } \\
\text { day }\end{array}$ & $\begin{array}{c}\text { Per } \\
\text { hour }\end{array}$ & $\begin{array}{c}\text { Per } \\
\text { day }\end{array}$ & $\begin{array}{c}\text { Per } \\
\text { hour }\end{array}$ \\
\hline Winter rye & 26.6 & 1.108 & 1.02 & 0.0425 \\
\hline Spring wheat & 21.6 & 0.900 & 1.14 & 0.0475 \\
\hline Spring barley & 29.2 & 1.217 & 1.24 & 0.0517 \\
\hline Oats & 35.9 & 1.496 & 1.38 & 0.0575 \\
\hline Grain crop average & 30.0 & 1.25 & 1.20 & 0.05 \\
\hline
\end{tabular}

The direct mechanical losses are also great. They include losses by roller headers and pick-ups during separate harvesting of grain and losses by combine headers with direct combine harvesting; losses downstream the thresher of the combine when threshing the grain mass. Indirect mechanical losses, that is to say damage to grain by the working bodies of machines, adversely affect the grain resistance to storage [2, 3].

The degree of injury during threshing depends on many factors: on the perfect design of the threshing devices of the harvesting machines, on the operating modes of their working bodies and the physical and mechanical properties of the grain at the time of threshing, including seed size and moisture. Micro-injured grains pose the greatest danger, since they cannot be isolated on cleaning and sorting machines, and they are the first to be affected by pathogenic microflora during storage.

According to the research of V.I. Orobinsky, I.V. Baskakov and A.V. Chernyshova, the level of grain injury can reach $47 \%$ (Table 2).

Table 2. Dependence of seed injury on their size and moisture at the time of threshing.

\begin{tabular}{|l|l|l|l|l|l|}
\hline The moisture & \multicolumn{5}{|c|}{$\begin{array}{c}\text { Degree of damage to seeds by fraction } \\
\text { content of the } \\
\text { [\%] in terms of fraction size [mm] }\end{array}$} \\
\cline { 4 - 7 } $\begin{array}{l}\text { grain at the of thresh- } \\
\text { time } \\
\text { ing [\%] }\end{array}$ & $3.2-3.0$ & $3.0-2.8$ & $2.8-2.6$ & $2.6-2.4$ & $2.4-2.2$ \\
\hline 10.3 & 32.1 & 28.2 & 26.7 & 30.3 & 31.7 \\
\hline 19.9 & 29.9 & 29.2 & 24.2 & 26.3 & 27.6 \\
\hline 29.6 & 47.0 & 35.7 & 33.3 & 37.1 & 44.4 \\
\hline
\end{tabular}

The seeds with a fraction of 2.8-2.6 mm harvested at a moisture content of $19.9 \%$ have the least degree of injury, which indicates the importance of favorable weather conditions and meeting harvesting dates.

The presence of a large amount of injured grain in the harvested grain degrades its commercial and sowing qualities, reduces the yield of future years, leads to an increase in storage losses, contributes to greater damage to the grain during subsequent processing. Due to mechanical damage, the gross grain yield is reduced 
annually by about 15 million metric tons of grain, which causes damage in the amount of over 1.5 billion rubles [8].

Given the transience of the phases of grain ripening (Table 3), it is necessary to organize monitoring of ripening in each field, starting 15 to 20 days before harvesting, based on the long-term average harvesting dates and agrometeorological conditions of the current year [2].

Table 3. The average duration of the phases of grain development.

\begin{tabular}{|l|c|}
\hline Grain development phase & Duration, days \\
\hline Gelatinous state & 10 to 12 \\
\hline Milky & 8 to 10 \\
\hline Pasty & 6 to 10 \\
\hline Wax ripeness & 6 to 8 \\
\hline Complete & 3 to 5 \\
\hline
\end{tabular}

Depending on the condition of the harvested grain, it is required to perform their post-harvest processing rather quickly, which in Russia, according to experts, should be immediate ( 2 to 5 days before processing) for more than half of the grain harvest.

In some years, many farms and region losses reached $10 \%$ of the harvest, which corresponds to the FAO estimate of the average global grain losses, but they are a reserve for increasing efficiency [9].

Against this background, the use of alternative technologies for the earlier harvesting of feed crops is especially justified. It is advisable to start harvesting fodder crops using a non-threshing method earlier than the start of harvesting food grains. At the same time, losses during threshing of grain are reduced significantly and special vehicles for transporting grain are not required, because straw is immediately transported from the field to storage sites. The technology is particularly justified in extreme weather conditions with the threat of loss of grain yield.

There are technologies for the preparation of flour, pellets, briquettes and grain silage from fodder grain crops harvested in this way.

At the same time, as it is known, the maximum content of both fodder units (FU) and digestible protein (DP) is reached by all crops during the wax ripeness period: $1 \mathrm{~kg}$ of dry matter contains $0.70-0.86 \mathrm{FU}$ and $80-90 \mathrm{~g}$ of DP; the FU content is 1.2 more and PP content is $1.5-2$ more here than during full ripeness. In the later stages of ripeness, the nutritional value decreases, the content of lignin, a digestive inhibitor, increases to $40 \%$.

Grain production in the form of grain silage is less energy-intensive being 60 to $70 \%$, on average due to the exclusion of process steps of drying, transportation, sorting and expensive storage of grain. The drying unit load is reduced by an average of 30 to $50 \%$ as compared with traditional processing of herbage. In addition, spike chaff, which has a nutritional value comparable to meadow hay, remains in the feed rather than in the field as with normal harvesting [2].

Flour, pellets, briquettes and grain haylage are made of grain crops harvested in this way.

Pellets made of grain crops harvested in the phase of milk-wax ripeness have a high feed value: $1 \mathrm{~kg}$ of dry matter contains 0.70 to 0.86 feed units, and 80 to $90 \mathrm{~g}$ of digestible protein.

It should be noted that issues of wider use of nontraditional sources and waste of crop production are discussed in the scientific community around the world. C. Devendra and C.C. Sevilla noted in their work that with a sufficiently large potential, there is a problem of insufficient involvement in the feeding of animals of unconventional feed and plant residues [10].

René Renato Balandrán-Quintana et al. note in their paper that agro-industrial wastes are economic sources of proteins that need to be involved, for which it is necessary to improve traditional extraction methods [11].

M. Gonzalez-Valadez et al. note that the use of extruder treatment of plant residues and low-cost industrial by-products in animal feed is a good alternative for farmers in developing countries, especially in the dry season due to lack of feed [12].

A technology for the cultivation of forage crops harvested in a non-threshing method is of practical interest. The optimal harvesting time is milk-wax ripeness. The high solids content in such an herbage (40$55 \%$ ) does not require its additional drying, it is immediately suitable for harvesting haylage after mowing and grinding, but bruising the herbage significantly speeds up the process. Haylage prepared, for example, from barley mass, contains $0.70-0.85 \mathrm{FU}$ in $1 \mathrm{~kg}$ of dry matter. In the total amount of organic acids, $82 \%$ is lactic acid; the digestibility of organic matter is 60 to $69 \%$. Loss of dry portion and protein in it does not exceed 12 to 13 $\%$.

In experiments on feeding bull-calves for fattening, an addition in the diet of $60-70 \%$ of chopped unthreshed barley grain haylage ensures an average daily gain in live weight of 790 to $831 \mathrm{~g}$ with a decrease in the cost of feed per $1 \mathrm{~kg}$ gain in live weight by 27 to $29 \%$.

The disadvantage is that the available equipment for the preparation of dehydrated feed does not provide a feed that is uniform in its nutritional value, since the grain and straw parts of the crushed plants are separated in the process of feed preparation. Therefore, mowing into a roll, rolling into coils of feed grains allows reducing the heterogeneity and loss of the grain part.

The effectiveness of the use of unthreshed grain fodder has shown its effectiveness. Experiments are known when a diet of dairy cows consisting of barley harvested in milk-wax ripeness, in the amount of $60 \%$, haylage $(30 \%)$ and root crops $(10 \%)$ provided an average daily milk yield of $19.5 \mathrm{~kg}$, while a diet consisting of silage and haylage $(50 \%)$, root crops $(10 \%)$, grass cutting $(10 \%)$ and concentrates $(30 \%)$, ensured the milk yield in the control group equal to $17.4 \mathrm{~kg}$. In experiments on fattening young cattle with such barley, the average daily gain in live weight was increased by 20 to $27 \%$ and the feed cost per unit of increase was reduced by 17 to $20 \%$ as compared to the use of feed mixture made of grain in full ripeness and straw. At the same time, the duration of fattening was reduced by 23-28 days. Fattening of bullcalves with a diet, which includes 60 to $70 \%$ of chopped unthreshed barley grain haylage, provides an average daily gain of 790 to $831 \mathrm{~g}$, while the cost of feed per $1 \mathrm{~kg}$ of live weight gain decreases by $27-29 \%$ [2]. 
Extrusion is an effective method of preparation of feed, because it allows combining mechanical, thermal and chemical influences simultaneously and continuously. Therefore, this method is widely integrated in a number of countries in the production of modified food products, such as cereals [13].

Such a combined effect changes the structure of fiber: there is dextrinization of starch to glucose, protein denaturation, inactivation of digestive tract inhibitors, neutralization of toxic substances, sterilization of feed and improvement of palatability. These qualitative changes increase the feed intake, as well as their digestibility accessibility in the animal's body [14].

At the same time, the accessibility of the grain components of feed increases on average by 30 to $40 \%$, and that of straw increases 2 to 2.5 times, the accessibility of rye increases from 10 to $90 \%$, and that of legumes increases from 7 to $80 \%$. In the course of such processing, humidity is reduced by 30 to $40 \%$, pathogenic microflora, helminth eggs, as well as harmful parasitic protozoa, insects and worms are destroyed in raw materials of substandard quality. This factor plays an important role in unfavorable sanitary conditions of feed raw materials.

It should be noted that the feed value of substandard raw materials after such processing exceeds 1.1 to 1.4 times the feed value of conditioned peers, since extrusion increases the digestibility of processed raw materials, makes them more accessible to the digestive systems of animals, poultry and fish, and also reduces enzyme and energy costs of the body for digestion and assimilation of the latter.

Studies have shown that products obtained after extrusion can be certified, meet accepted standards for nutrition and the content of an appropriate set of vitamins and minerals, are veterinarily safe and environmentally friendly. At the same time, the problems of recycling crop waste and waste from the other agricultural industries, as well as problems of waste processing, are solved, which can address the environmental aspects of production facilities. The average cost of producing $1 \mathrm{~kg}$ of extruded feed is commensurate with the cost of $1 \mathrm{~kg}$ of feed grain, while the feed value exceeds 1.5-3.0 times the feed grain [2].

Table 4 shows that as a result of extrusion, the nutrient content increases in the feed of natural moisture. When calculating the content of the studied parameters in absolutely dry matter, the total nutritional value (in feed units) and metabolic energy did not change, but the protein content increased by $3 \%$ and $4 \%$ respectively, the sugar content increases by $62 \%$ and $143 \%$ in rye and wheat, respectively. The results indicate an increase in feed value and nutritional value as a result of extrusion [15].

The developed technology for the production of mono-feed excludes operations for separation, threshing, cleaning and drying, as well as disposal of straw; all portions of the spikes and the stalks, after processing, turn into the so-called mono-feed, an analogue of expensive feed grain. It is easier to digest and has a higher nutritional value. Cereals in the phase of milk-wax ripeness are mowed in a roll and rolled up in the fodder grain coils. Rolls are transported to storage.
At the same time, direct and indirect biological and mechanical losses of grain associated with harvesting and transportation are reduced, the issue of the rational use of straw and floor is addressed. Un-threshed grain feed is extruded into mono-feed as needed.

Table 4. Chemical composition of the grain before and after extrusion.

\begin{tabular}{|c|c|c|c|c|c|c|}
\hline \multirow[t]{2}{*}{ Parameter } & \multicolumn{3}{|c|}{ Rye } & \multicolumn{3}{|c|}{ Wheat } \\
\hline & Before & After & $\begin{array}{c}\text { Differe } \\
\text { nce }\end{array}$ & Before & After & $\begin{array}{c}\text { Differe } \\
\text { nce }\end{array}$ \\
\hline \multicolumn{7}{|c|}{ Content in $1 \mathrm{~kg}$ of natural moisture } \\
\hline 1. Feed units & 1.09 & 1.16 & +0.07 & 1.11 & 1.16 & +0.05 \\
\hline $\begin{array}{l}\text { 2. Metabolic } \\
\text { energy }[\mathrm{MJ}]\end{array}$ & 10.76 & 11.47 & +0.71 & 10.89 & 11.38 & +0.49 \\
\hline \begin{tabular}{|lr}
3. & Crude \\
protein $[\mathrm{g}]$
\end{tabular} & 109.8 & 120.6 & +10.8 & 126 & 139 & +13 \\
\hline $\begin{array}{l}\text { 4. Digestible } \\
\text { protein }[\mathrm{g}]\end{array}$ & 91.13 & 91.6 & +0.53 & 110.9 & 121.5 & +10.6 \\
\hline 5. Sugar $[\mathrm{g}]$ & 63.8 & 110 & +46.2 & 36.4 & 93.2 & +56.8 \\
\hline \multicolumn{7}{|c|}{ Content in $1 \mathrm{~kg}$ of absolutely dry matter } \\
\hline 1. Feed units & 1.27 & 1.27 & 0 & 1.28 & 1.28 & 0 \\
\hline $\begin{array}{|lr|}2 . & \text { Metabolic } \\
\text { energy }[\mathrm{MJ}]\end{array}$ & 12.54 & 12.54 & 0 & 12.5 & 12.5 & 0 \\
\hline \begin{tabular}{|lr} 
3. & Crude \\
protein $[\mathrm{g}]$
\end{tabular} & 127.9 & 131.8 & +3.9 & 145.3 & 151.2 & +5.9 \\
\hline 4. Sugar $[\mathrm{g}]$ & 74.4 & 120.3 & +45.9 & 42.0 & 102.4 & +60.4 \\
\hline
\end{tabular}

The extrusion of unthreshed grain fodder harvested in the phase of milk-wax ripeness ensures good eatability, digestibility and increases its feed value. The ratio of the weight of grain in the spike to the straw weight is 60/40, the so-called "dead waste" (weeds and their seeds) also become a nutrient of the extrudate. As it is known, the digestibility of grain increases by 30 to $40 \%$, and that of straw increases 2 to 2.5 times, the digestibility of rye increases from 10 to $90 \%$, and that of legumes from 7 to $80 \%$. During this treatment, humidity is reduced by 30 $40 \%$, pathogenic microflora, helminth eggs, as well as harmful parasitic protozoa, insects and worms are destroyed in raw materials of substandard quality. The resulting feed is highly nutritious (protein content reaches 22 to $24 \%$ ), has easier digestibility, biological activity, as well as enzyme, vitamin and mineral value.

As it is known, there is a higher grain content in traditional domestic formulations of animal feed (60 to 80 $\%$ ), while it is $12-15 \%$ in many countries of developed animal husbandry. This along with significant competition with the food industry for grain resources stimulate the improvement of feed preparation technologies and the improvement of the quality of the feed base, including those through the involvement of crop waste [16].

Therefore, the discussed processes for harvesting grain forage, storage, silting, or extrusion allow solving a number of problems:

- Optimizing harvesting campaign by postponing the harvesting of feed crops to an earlier date;

- Reducing the need for cereals by increasing the nutritional value of feed

- involving in the feeding resources traditionally used as crop wastes, irrationally unused and being often in need 
of preparation operations for storage or recycling, as well as to use deteriorated and damaged feed raw materials, which have lost the necessary level of sanitary and hygienic performance and cannot be used in feeding without appropriate processing, for example, extrusion.

\section{Conclusion}

The method of mowing cereals in the phase of milk-wax ripeness in a roll, rolling up in rolls and transportation for storage has proven itself well. At the same time, direct and indirect biological and mechanical losses of grain associated with harvesting and transportation are reduced, the issue of the rational use of straw and sex is solved.

The processes of haying and extrusion of unthreshed grain haylage ensures the production of feed with high zootechnical and consumer performance and characterized by high levels of nutrition, digestibility and biological value.

After extrusion, the resulting mono-feed features high nutrition (protein content is 22-24\%), easier digestibility, biological activity, as well as enzyme, vitamin and mineral value.

An important feature of these technologies is their integration, which consists in the ability to simultaneously solve the most important problems of agricultural enterprises, including reducing dependence on cereals that are the main structural component of the diet, providing farms with high-quality feed while reducing the overall cost of this item and solving the environmental issue such as waste recycling, which is very important in the framework of the tasks set by the government for resource conservation.

The main indicator of the efficiency of processing of unthreshed grain fodder is a significant reduction in the cost of livestock products and an increase in the profitability of production. The process of unthreshed harvesting of grain crops is especially justified in extreme weather conditions with the threat of loss of grain yield.

\section{References}

1. Yunbi Xu, Jiayang Li, Jianmin Wan, Agriculture and crop science in China: Innovation and sustainability, The Crop J., 5(2) 04, 95-99 (2017) available at: https://doi.org/10.1016/j.cj.2017.02.002.

2. O.Yu. Krasilnikov, T.E. Marinchenko, The relevance of effective feed production, Agrarian Bull. of the South-East, 2(19), 44-46 (2018)

3. V. Pakhomov, A. Alferov, S. Braginets, O. Bakhchevnikov, D. Rudoi, Production of feed in an extruder-grinder with herbage input, Feed compound, 3 29-31 (2019) DOI 10.25741/2413287X-2019-03-2-050.

4. N.P. Mishurov, S.A. Davydova, A.A. Davydov, Innovative methods of heat treatment of animal feed, Machinery and equipment for rural area, 3, 2-7 (2019)

5. N.M. Morozov, Organizational, economic and technological foundations of mechanization and automation of animal husbandry (Rosinformagrotekh, Moscow, 2011) $284 \mathrm{p}$.

6. The share of food wheat in the 2019 crop exceeded $80 \%$ : Russian Agricultural Center, available at: https://rosselhoscenter.com/index.php/zerno-iprodukty-ego-pererabotki/19911-ob-itogakh-rabotyfgbu-rosselkhoztsentr-v-oblasti-otsenki-kachestvazerna-i-produktov-ego-pererabotki-za-2019-god.

7. Long-term strategy for the development of the grain facilities of the Russian Federation until 2025 and for the future until 2035, available at: http://mcx.ru/upload/iblock/04c/04c91c2c72fbd7735 40ec908f9410edd.pdf.

8. V.I. Orobinsky, I.V. Baskakov, A.V. Chernyshov, Reduced grain injury during harvesting (Voronezh State Agrarian University, Voronezh, 2017) 161 p.

9. S.K. Manasyan, I.S. Andguladze, Grain storage: problems, approaches to solving, in: Problems of modern agricultural science: Mat. Int. Scientific Conf., available at: http://www.kgau.ru/new/all/konferenc/konferenc/20 13/d4.pdf.

10. C. Devendra, C.C. Sevilla, Availability and use of feed resources in crop-animal systems in Asia, Agricultural Systems, 71(01-02), 59-73 (2002) available at: https://doi.org/10.1016/S0308$\underline{521 X(01) 00036-1}$

11. R.R. Balandrán-Quintana, A.M. Mendoza-Wilson, G. Ramos-Clamont Montfort, J.Á. Huerta-Ocampo, Chapter 4 - Plant-Based Proteins, in: Proteins: Sustainable Source, Processing and Applications (2019) pp. 97-130, available at: https://doi.org/10.1016/B978-0-12-816695-6.00004$\underline{0}$

12. M. Gonzalez-Valadez, G. Munoz-Hernandez, R. Sanchez-Lopez, Design and evaluation of an extruder to convert crop residues to animal feed, Biosystems Engineering, 100(1) 05, 66-78 (2008) available

at: https://doi.org/10.1016/j.biosystemseng.2008.02.002

13. V. Vandenbossche, L. Candy, P.-Y. Pontalier, Chapter 10 - Extrusion Green Food Processing Techniques, in: Preservation, Transformation and Extraction (2019) pp. 289-313, available at: https://doi.org/10.1016/B978-0-12-815353-6.00010$\underline{0}$

14. V.I. Pakhomov, S.V. Braginets, O.N. Bakhchevnikov, A.S. Alferov, U.V. Stepanova, The results of experimental studies of the process of co-extrusion of feed grain and herbage of alfalfa, Bull. of Kursk State Agricultural Academy, 9, 45-48 (2017)

15. E.V. Slavnov, E.V. Pepelyaeva, M.A. Trutnev, Extrusion processing of freshly harvested grain of natural moisture content, Agrarian Bull. of the Urals, 8(100), 49-50 (2012)

16. T.E. Marinchenko, Unusual feeds to help the farmer, Machinery and equipment for rural area, 2, 43-47 (2011) 